ISSN $2623-6575$

GLASILO

FUTURE

UDK 60

UDK 631

UDK 630

UDK 336

UDK 338

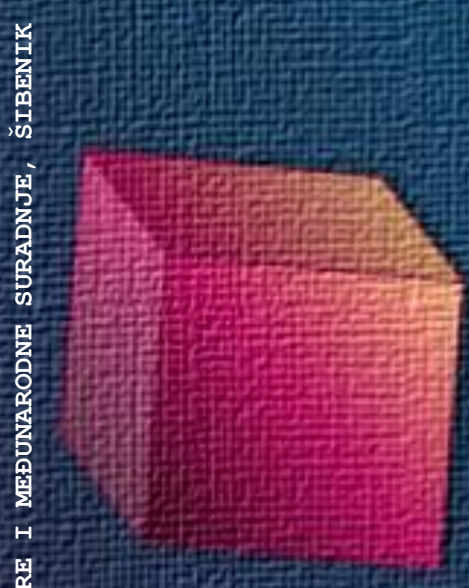

5
5
5

î

s.

䐱

5
5
0
0
0
0
0

A

8

S

竞

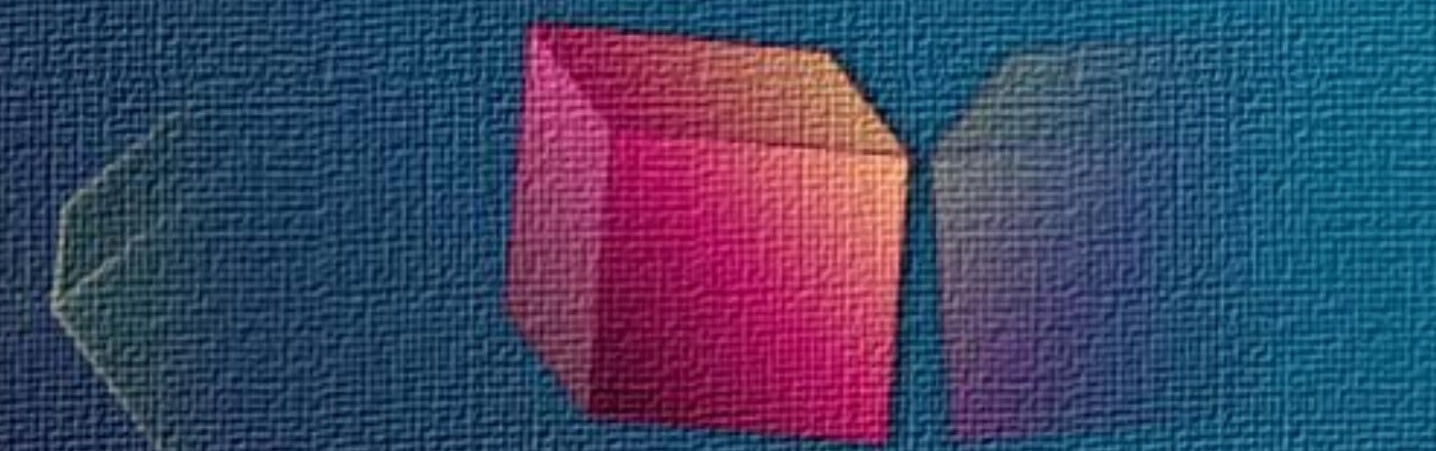

(1) 


\section{Glasilo Future}

\section{Stručno-znanstveni časopis}

Nakladnik: FUTURA

\section{FUTUR}

Sjedište udruge: Šibenik

\section{Adresa uredništva:}

Bana Josipa Jelačića 13 a, 22000 Šibenik, Hrvatska / Croatia 留 / 圆: +385 (0) 022218133

$\triangle$ : urednistvo@gazette-future.eu / editors@gazette-future.eu (3): www.gazette-future.eu

\section{Uređivački odbor / Editorial Board:}

Doc. dr. sc. Boris Dorbić, v. pred. - glavni i odgovorni urednik / Editor-in-Chief

Emilija Friganović, dipl. ing. preh. teh., v. pred. - zamjenica g. i o. urednika / Deputy Editor-in-Chief

Ančica Sečan Matijaščić, mag. act. soc. - tehnička urednica / Technical Editor

Antonia Dorbić, mag. art. - zamjenica tehničke urednice / Deputy Technical Editor

Prof. dr. sc. Željko Španjol

Mr. sc. Milivoj Blažević

Vesna Štibrić, dipl. ing. preh. teh.

\section{Međunarodno uredništvo / International Editorial Board:}

Prof. dr. sc. Kiril Bahcevandziev - Portugal (Instituto Politécnico de Coimbra)

Prof. dr. sc. Martin Bobinac - Srbija (Šumarski fakultet Beograd)

Doc. dr. sc. Zvezda Bogevska - Makedonija (Fakultet za zemjodelski nauki i hrana Skopje)

Dario Bognolo, mag. ing. - Hrvatska (Veleučilište u Rijeci)

Prof. dr. sc. Agata Cieszewska - Poljska (Szkoła Główna Gospodarstwa Wiejskiego w Warszawie)

Dr. sc. Bogdan Cvjetković, prof. emeritus - Hrvatska (Agronomski fakultet Zagreb)

Prof. dr. sc. Duška Ćurić - Hrvatska (Prehrambeno-biotehnološki fakultet Zagreb)

Doc. dr. sc. Margarita Davitkovska - Makedonija (Fakultet za zemjodelski nauki i hrana Skopje)

Doc. dr. sc. Dubravka Dujmović Purgar - Hrvatska (Agronomski fakultet Zagreb)

Prof. dr. sc. Semina Hadžiabulić - Bosna i Hercegovina (Agromediteranski fakultet Mostar)

Prof. dr. sc. Péter Honfi - Mađarska (Faculty of Horticultural Science Budapest)

Prof. dr. sc. Valeria Ivanova - Bugarska (Fakultet za lozaro-gradinarstvo Plovdiv)

Doc. dr. sc. Orhan Jašić - Bosna i Hercegovina (Filozofski fakultet Tuzla)

Prof. dr. sc. Tajana Krička - Hrvatska (Agronomski fakultet Zagreb)

Prof. dr. sc. Biljana Lazović - Crna Gora (Biotehnički fakultet Podgorica)

Prof. dr. sc. Bosiljka Mustać - Hrvatska (Sveučilište u Zadru)

Hrv. akademik prof. dr. sc. Stanislav Nakić - Bosna i Hercegovina (Sveučilište Hercegovina Mostar)

Sandra Popović, mag. ing. - Srbija (Poljoprivredni fakultet Beograd)

Doc. dr. sc. Bojan Simovski - Makedonija (Šumarski fakultet Skopje)

Prof. dr. sc. Davor Skejić - Hrvatska (Građevinski fakultet Zagreb)

Doc. dr. sc. Milan Stanković - Srbija (Univerzitet u Kragujevcu)

Akademik prof. dr. sc. Refik Šećibović - Bosna i Hercegovina (Visoka škola za turizam i menadžment Konjic)

Prof. dr. sc. Andrej Šušek - Slovenija (Fakulteta za kmetijstvo in biosistemske vede Maribor)

Prof. dr. sc. Elma Temim - Bosna i Hercegovina (Agromediteranski fakultet Mostar)

Doc. dr. sc. Ivana Vitasović Kosić - Hrvatska (Agronomski fakultet Zagreb)

Doc. dr. sc. Ana Vujošević - Srbija (Poljoprivredni fakultet Beograd)

Prof. dr. sc. Vesna Židovec - Hrvatska (Agronomski fakultet Zagreb)

Lektura i grafička priprema: Ančica Sečan Matijaščić, mag. act. soc.

Objavljeno: 31. prosinca 2018. godine.

Časopis izlazi u elektroničkom izdanju dva puta godišnje, krajem lipnja i prosinca, a predviđena su i dva interdisciplinarna specijalna izdanja tijekom godine iz STEM i ostalih znanstvenih/umjetničkih područja.

Časopis je besplatan. Rukopisi i recenzije se ne vraćaju i ne honoriraju.

Umnožavanje (reproduciranje), stavljanje u promet (distribuiranje), priopćavanje javnosti, stavljanje na raspolaganje javnosti odnosno prerada u bilo kojem obliku nije dopuštena bez pismenog dopuštenja Nakladnika. Sadržaj objavljen u Glasilu Future može se slobodno koristiti u osobne i obrazovne svrhe uz obvezno navođenje izvora. 


\section{Glasilo Future}

\section{Stručno-znanstveni časopis}

FUTURA - stručno-znanstvena udruga za promicanje održivog razvoja, kulture i međunarodne suradnje, Bana Josipa Jelačića 13 a, 22000 Šibenik, Hrvatska

(2018) 1 (4) 01-54

\section{SADRŽAJ:}

Izvorni znanstveni rad (original scientific paper)

Str.

B. Dorbić, Sandra Dukić, Emilija Friganović, Margarita Davitkovska,Zvezda Bogevska, Ana Vujošević, Sandra Popović

Percepcije i stavovi o ukrasnim karakteristikama i primjeni submediteranskog

listopadnog drveća u zimskom razdoblju

Perceptions and attitudes about ornamental characteristics of sub-mediterranean

deciduous trees during the winter season

\section{Stručni rad (professional paper)}

\section{Z. Maričić, L. Maričić}

Optimiziranje portfelja s različitim brojem imovine i različitim preferencijama rizika Portfolio optimization with different number of assets and different risk preferences

L. Maričić, Z. Maričić

Utjecaj dodatnih dionica na granice efikasnosti, portfelj s minimalnom varijancom i tangencijalni portfelj

Influence of additional shares on efficiency frontier, minimum variance portfolio and tangential portfolio

\section{Nekategorizirani rad (uncategorised paper)}

\section{B. Dorbić}

Prikaz knjige

Book review

\section{B. Dorbić}

Društvene vijesti

Social news 
B. Dorbić, Sandra Dukić, Emilija Friganović, Margarita Davitkovska, Zvezda Bogevska, Ana Vujošević, Sandra Popović / Percepcije i stavovi o ukrasn... / Glasilo Future (2018) 1 (4) 01-16

\title{
Percepcije i stavovi o ukrasnim karakteristikama i primjeni submediteranskog listopadnog drveća u zimskom razdoblju
}

\section{Perceptions and attitudes about ornamental characteristics of sub-mediterranean deciduous trees during the winter season}

\author{
Boris Dorbic $^{1 *}$, Sandra Dukić ${ }^{2}$, Emilija Friganović ${ }^{1}$, Margarita Davitkovska ${ }^{3}$, Zvezda Bogevska ${ }^{4}$, \\ Ana Vujošević ${ }^{4}$, Sandra Popović ${ }^{5}$
}

izvorni znanstveni rad (original scientific paper)

doi: $10.32779 / g f .1 .4 .1$

\section{Sažetak}

Kod projektiranja različitih krajobraznih površina odabir prikladnog drveća vrlo je važan jer ono često određuje izgled i ugodu otvorenom prostoru. Potrebno je uzeti u obzir ukrasne vrijednosti vrste tijekom cijele godine. I u zimskom razdoblju neko listopadno drveće može pokazati svoje dekorativne vrijednosti. U submediteranskom klimatu, kojem pripada i grad Knin, može se izdvojiti desetak vrsta drveća s jednom ili više ukrasnih karakteristika (habitus, kora, deblo, grane, grančice i plodovi) u zimskom razdoblju. To su sljedeće vrste: Celtis australis L., Ulmus pumila L., Tilia cordata Mill., Morus nigra L., Aesculus hippocastanum L., Acer negundo L. i dr. Slijedom navedenog, cilj rada je bilo istraživanje percepcija i stavova o ukrasnim karakteristikama i primjeni listopadnog submediteranskog drveća u zimskom razdoblju. Anketno istraživanje je provedeno tijekom travnja i svibnja 2017. godine na uzorku od 50 ispitanika s područja grada Knina i okolice. Temeljem navedenih istraživanja došlo se do spoznaja da ispitanici sa područja grada Knina i njegove okolice s prosječnom ocjenom dobar vrednuju ukrasne karakteristike i primjenu za osam od devet odabranih vrsta drveća. Najbolje ocjene su dodijelili hibridnoj platani Platanus $x$ hispanica Münchh. Vrsta im se najvjerojatnije dopada zbog njenog neobičnog izgleda (habitus, plod, deblo itd.) i manje primjene u parkovima i krajobraznim površinama. Rezultati ovog istraživanja mogu biti iskorišteni kod projektiranja različitih krajobraznih površina u smislu povećanja ugode i zadovoljstva korisnika.

Ključne riječi: listopadno drveće, zimsko razdoblje, estetika, percepcija, Knin.

\footnotetext{
${ }^{1}$ Veleučilište "Marko Marulić" u Kninu, Krešimirova 30, 22300 Knin, Republika Hrvatska.

* Doc. dr. sc. Boris Dorbić, v. pred., e-mail: bdorbic@veleknin.hr.

${ }^{2}$ Završena studentica preddiplomskog stručnog studija Poljoprivreda krša smjer Biljna proizvodnja.

${ }^{3}$ Univerzitet Sv. Kiril i Metodij Skopje, Fakultet za poljoprivredne znanosti i hranu Skopje, Ul. 16 Makedonska brigada br. 3, 1000 Skopje, Republika Makedonija.

${ }^{4}$ Poljoprivredni fakultet Univerziteta u Beogradu, Nemanjina 6, 11080, Beograd-Zemun, Republika Srbija.
} 


\section{Abstract}

The selection of appropriate trees is extremely important whilst designing different landscape surfaces, since it frequently defines both the appearance and the comfort of the open space. Ornamental values of the tree species throughout the year need to be considered. Some deciduous trees can show their ornamental value even during the winter season. Due to one or more ornamental characteristics (habitus, tree bark, tree trunk, branches, twigs and fruits) during the winter season, around 10 species of trees can be highlighted in the sub-Mediterranean climate, which is also the climate in the city of Knin. They include the following tree species: Celtis australis L., Ulmus pumila L., Tilia cordata Mill, Morus nigra L., Aesculus hippocastanum L., Acer negundo L. etc. Consequently, the objective of this paper was to conduct research on perceptions and attitudes about ornamental characteristics and the use of deciduous sub-Mediterranean trees during the winter season. The survey research was conducted in April and May of 2017 on a sample of 50 respondents originating from the area of the city of Knin and its outskirts. Based on the findings of the previously mentioned research, the conclusion was reached that the respondents originating from the city of Knin and its outskirts evaluated the ornamental characteristics for the use of eight out of nine selected tree species with the average grade good. The hybrid plane tree referred to as London plane or Platanus $x$ hispanica Münchh received the highest grade. They most probably liked this species due to its unusual appearance (habitus, fruit, tree trunk etc.) and its less frequent use in parks and landscape surfaces. The findings of this research can be used for the purpose of design of different landscape surfaces aimed at increasing user comfort and satisfaction.

Key words: deciduous trees, winter season, aesthetics, perception, Knin.

\section{Uvod}

Prilikom projektiranja krajobraznih površina odabir prikladnog drveća i grmlja je vrlo važan jer ono često određuje izgled otvorenog prostora. Uspješan odabir bilja dobiva se analizom funkcionalnih $i$ strukturnih karakteristika, vizualnih i ostalih osjetnih karakteristika, habitusa biljaka i stanišnih zahtjeva. Vidljive karakteristike drveća (izdanci, kora, plodovi, deblo itd.) također su značajni prilikom oblikovanja krajobraznih površina ili nasada (Kravanja, 2005, str. 88). Vidne karakteristike su bitan kriterij izbora vrste za krajobraz kako u prošlosti tako i sada (Dobrilović, 2005). Kod percepcije ukrasnih karakteristika drveća i grmlja ispitanici u okviru nekih istraživanja u Sloveniji više preferiraju grmove te bjelogorične vrste (Kravanja, 2005). Odabir biljnih vrsta $\mathrm{i}$ ispravno parkovno uređenje zacijelo ima utjecaj i na boravak korisnika (Dorbić i Temim, 2014). U oblikovanju prostora sudjeluje niz elemenata koji se prožimaju i stvaraju njegovu novu dimenziju (Grašo, 2005). Od prvobitne reprezentativne i dekorativne funkcije danas se više traže socijalne i suprirodne ili čak prirodne funkcije. Biološka raznolikost $i$ kako vratiti prirodu u grad veliki su izazov za projektante 
B. Dorbić, Sandra Dukić, Emilija Friganović, Margarita Davitkovska, Zvezda Bogevska, Ana Vujošević, Sandra Popović / Percepcije i stavovi o ukrasn... / Glasilo Future (2018) 1 (4) 01-16

(Šiftar, 2003, prema Židovec i Karlović, 2005).

Kravanja (2015) temeljem istraživanja zaključuje da je za dopadljivost biljke možda važan i njen neobičan oblik od izgleda uobičajenih parkovnih vrsta. Upravo zbog navedenog je potrebno prilikom krajobraznog projektiranja razmišljati više i o ukrasnim vrijednostima listopadnog drveća u zimskom razdoblju. Osim neobičnog habitusa takve vrste može krasiti neobična kora, deblo, grane, grančice i plodovi. U submediteranskom klimatu može se izdvojiti desetak takovih vrsta s jednom ili više navedenih ukrasnih karakteristika.

Bilo bi poželjno koristiti naše autohtone ili autentične submediteranske vrste kao što su npr: crni dud, crni jasen, košćela, sitnolisna lipa itd. Šišić i Kapović (2004) naglašavaju da su se domaće biljne vrste u funkciji krajobraznog uređenja pokazale najpodesnijima jer da se nova naselja jednostavnije integriraju u okolne prostore slobodne prirode. Zato je bitno kod promatranja i biranja biljnih vrsta jednako važno uvažiti karakteristike koje potječu iz okoline (Dobrilovič, 2005). Važno je istaknuti da je u temelju pojma parkovne arhitekture ideja identiteta (Manojlović, 2005).

\section{Materijali i metode}

Prilikom izrade rada, kao izvor primarnih podataka, korišteno je anketno istraživanje na području grada Knina i okolice. Za sekundarne podatke korištene su različite publikacije i radovi (stručni i znanstveni). Cilj anketnog istraživanja bilo je istraživanje percepcija i stavova o ukrasnim karakteristikama i primjeni listopadnog submediteranskog drveća u zimskom razdoblju. Anketno istraživanje je provedeno tijekom travnja i svibnja 2017. godine na uzorku od 50 ispitanika s područja grada Knina i okolice (24 muškarca i 26 žena). Ispitanici su, pored anketnog upitnika, zbog bolje percepcije, dobili na uvid i fotografije ukrasnih karakteristika drveća u zimskom razdoblju. Starosna struktura uzorka bila je: do 20 godina (4), 20 - 30 godina (23), 30 - 40 godina (12), 40 - 50 godina (7), 50 - 65 godina (2), 65 i više godina (2) ispitanika, a izbor ispitanika je bio slučajan. U pogledu stupnja obrazovanja struktura uzorka je bila: srednja stručna sprema (23), viša stručna sprema (17), visoka stručna sprema (8) i završeni magisterij ili doktorat znanosti (2) ispitanika. U tu svrhu korištena je petostupanjska Likertova ljestvica s vrijednostima od 1 do 5.

Obrada podataka provedena je mjerilima centralne tendencije tj. na osnovi izračuna aritmetičke sredine i standardne devijacije. Statistička obrada podataka je izvršena u programu SPSS 14,0 za Windows sučelje.

\section{Rezultati i rasprava}

\section{Morfološke karakteristike listopadnog drveća u zimskom razdoblju}

Drveće je građeno od korijena i nadzemnog drvenastog izdanka stabljike (deblo i krošnja) na kojem se 
B. Dorbić, Sandra Dukić, Emilija Friganović, Margarita Davitkovska, Zvezda Bogevska, Ana Vujošević, Sandra Popović / Percepcije i stavovi o ukrasn... / Glasilo Future (2018) 1 (4) 01-16

razvijaju listovi, cvjetovi i plodovi. Listopadnim vrstama u jesen svake godine otpada lišće. Tijekom vegetacijskog razdoblja lišćem postaju obrasli jedino jednogodišnji izbojci. Tipičan izgled odnosno habitus pojedine vrste ili roda nastaje zbog specifičnog rasta i sustava razgranjenja. On ovisi o izgledu krošnje i debla. Svi sporedni ogranci koji rastu iz debla sačinjavaju krošnju. Granama se nazivaju stariji i jači sporedni ogranci. Tanji ogranci se pak nazivaju izbojci. Za drveće je tipičan akrotan način razgranjenja, smješten na vršcima glavne osi. Habitus se mijenja ovisno o starosti biljke, a i pod utjecajem okoline. Prema obliku može biti pravilan i nepravilan. Nepravilan habitus nastaje kada nije jasno izražena glavna os ili kada su grane i izbojci različitih veličina. Pravilan habitus karakteriziraju različiti pravilni oblici krošnje: okruglasti, jajasti, čunjasti i stupasti. Prema smjeru rasta grana ili debla habitus može biti: uspravan, uzak, priklonit, ravan, nagnut, poniknut, viseći, podignut, povitljiv, vijugav itd. (Idžojtić, 2005).

Deblo, grane i izbojke prekriva kora. Kora se dijeli na primarnu i sekundarnu. Primarnu koru prekriva epiderma, odnosno zaštitno jednoslojno kožno staničje. S vanjske strane kambija između kambijskog plašta i primarne kore nastaje sekundarna kora. Svaka pojedina vrsta ima specifičan izgled kore i može poslužiti u određivanju vrste. Primjerice, kod nekih vrsta lila je uzdužno ili poprečno izbrazdana, a kod drugih uzdužno i poprečno izbrazdana. Ovisno o vrsti ona se ljušti (odljepljuje) na različite načine i u različitim oblicima: u dugačkim širokim trakama, u nitima, u obliku ljuskica, u krpama, ili prstenasto u horizontalnim trakama. Već u prvoj godini, kada kora počinje rasti u debljinu, na mjestu pući nastaju jasno vidljive lenticele, sastavljene od rahlog staničja širokih međustaničnih prostora (Idžojtić, 2005).

Izbojci su mladi ogranci drveća koji svake godine rastu iz pupova i potom odrvene. U zimskom razdoblju izbojak listopadnih vrsta sastoji se od osi izbojka i pupova koji su smješteni na nodijima, koljencima ili čvorovima. Prema intenzitetu razvoja razlikuju se dugi i kratki izbojci. Iz vršnih pupova razvijaju se dugi izbojci, dugih internodija pomoću kojih biljka raste u dužinu. U skupinu kratkih izbojaka spadaju svi oni izbojci koji imaju ograničen vijek trajanja, a razvili su se na prošlogodišnjem dugom izbojku. Izgled ovogodišnjih izbojaka vrlo je bitan element kod određivanja vrsta u zimskom razdoblju. Svaki izbojak karakterističan je po obliku, debljini, površini i boji, te različitim izraslinama kao što su bodlje, trnovi, vitice i slično. Nakon opadanja listova na izbojcima ostaju ožiljci otpalih listova i ožiljci palistića. Osim izgleda kore i izbojaka, izgled pupova (raspored, broj, veličina, boja) također može biti od iznimne važnosti za prepoznavanje listopadnih vrsta tijekom zimskog razdoblja. Na izbojcima se mogu nalaziti i trnovi, bodlje, korjenčići, vitice i bodlje (Idžojtić, 2005).

Pupovi su svi mladi izdanci s nerazvijenim internodijima, gusto raspoređenim mladim, lisnim zametcima na čijem vrhu se nalazi vegetacijski vrh. Raspored, veličina, broj, boja, oblik ljusaka i prekrivenost dlakama važne su prilikom identifikacije vrste u zimskom razdoblju. Prema položaju razlikuju se vršni i postrani pupovi. Vršni pupovi su svi oni pupovi koji su smješteni na vrhu izbojka, a postrani su svi pupovi koji se razvijaju u nodijima, u pazušcu listova (Idžojtić, 2005). 
B. Dorbić, Sandra Dukić, Emilija Friganović, Margarita Davitkovska, Zvezda Bogevska, Ana Vujošević, Sandra Popović / Percepcije i stavovi o ukrasn... / Glasilo Future (2018) 1 (4) 01-16

Kod nekih vrsta drveća plodovi se zadržavaju u zimskom razdoblju. Velik broj vrsta zadržava ih djelomično, te tijekom zime oni postupno otpadaju. Kod određivanja vrste mogu poslužiti i plodovi (Idžojtić, 2005).

Tablica 1. Morfološke karakteristike odabranog drveća koje je ukrasno u zimskom razdoblju.

Table 1. Morphological characteristics of selected trees that are decorative in the winter period.

\section{Morfološki opis}

Celtis australis $\mathrm{L}$.

Koštela je listopadno stablo iz porodice brijestova. Izuzetno je jakog debla koje doseže visinu do 20 metara, s okruglastom i prozračnom krošnjom. Istu sačinjavaju tanke sivosmeđe grančice. Kora joj je debela, siva te dugo vremena ostaje glatka. Plodovi su okruglaste, tamnoljubičaste koštunice, promjera od oko $1 \mathrm{~cm}$. Dozrijevaju u srpnju i kolovozu, te na stablu mogu ostati preko čitave zime (Šilić, 1990). Ulmus pumila $\mathrm{L}$.

Sibirski brijest je do $20 \mathrm{~m}$ visoko drvo okruglaste krošnje. Kora mu je tamnosive boje, uzdužno izbrazdana. Izbojci su tanki, sivi, goli sa sivim lenticelama (Idžojtić, 2005). Plod brijesta je jedno sjemeni oraščić, bjelkasto žute boje (Šilić, 1990).

Tilia cordata Mill.

Sitnolisna lipa je listopadna vrsta iz porodice sljezovki čije stablo doseže visinu od oko $25-30 \mathrm{~m}$, s dobro razvijenom, jajolikom, duguljastom krošnjom. Kora debla u mladosti je glatka i zelenkastosmeđe boje, a starenjem stabla postaje dublje uzdužno izbrazdana te poprimi crvenkastosivu boju (Šilić, 1990). Izbojci sitnolisne lipe su tanki i okruglasti, crvenkastosmeđe do žutosmeđe boje, posuti svjetlijim lenticelama. Plod je tvrdi okruglasti oraščić, smeđe boje (Idžojtić, 2005).

Morus nigra L.

Crni dud je listopadna, jednodomna vrsta iz porodice dudova. Stablo je guste krošnje i visine do $20 \mathrm{~m}$ (Hulina, 2011). Kora debla je sivo smeđa i brazdasto ispucana. Izboji su crvenkastosmeđi u jesen posmeđe (Vukičević, 1987). Plod je crna srašljika (Hulina, 2011). Korijen je dobro razvijen.

Aesculus hippocastanum L.

Divlji kesten je listopadno stablo visine 20 - 30 metara, i širine debla od oko $100 \mathrm{~cm}$, široko razgranate, okruglaste krošnje (Šilić, 1990). Kora je tamnosmeđe do sivosmeđe boje i ljuskasta. Izbojci su ravni, debeli, goli, smeđe boje (Idžojtić, 2005). Plod divljeg kestena okrugli je tobolac promjera od oko $6 \mathrm{~cm}$, tamnosmeđe boje s vanjskim bodljama (Šilić, 1990).

Platanus $x$ hispanica Münchh

Hibridna platana je listopadno stablo do 40 metara visoko, s velikom razgranatom krošnjom. Kora debla je šarena, u tonovima smeđe i sive boje, ljušti se u krpama. Izbojci su koljenčasti, crvenkastosmeđi do zelenkastosmeđi okruglasti, goli, posuti lenticelama. Plod hibridne platane okruglasta je, skupno plodna glavica, promjera $2-2,5 \mathrm{~cm}$, smeđe boje (Idžojtić, 2005).

Fraxinus ornus L.

Crni jasen je listopadno stablo visine 15 - 20 metara, gusto razgranate krošnje i kratkog krivudavog debla s korom u tonovima sive boje, koja dugo vremena ostaje glatka. Izbojci su ravni, zadebljali i glatki, smeđe ili zelenkaste boje, prekriveni svjetlijim lenticelama. Plod crnog jasena okruglasti je oraščić dužine od oko $3 \mathrm{~cm}$, smeđe boje (Idžojtić, 2005).

Acer negundo L.

Javor negundovac je listopadno dvodomno stablo, koje doseže visinu do 15 metara u okviru svog prirodnog areala, dok je u kulturi znatno manje visine. Deblo je izrazito, guste krošnje, koju sačinjavaju duge šibolike grančice (Šilić, 1990). Kora debla kod mlađih stabala tanka je i glatka, uzdužno izbrazdana, u početku zelenkaste, a kasnije svijetlosive do smeđe boje, s dubljim brazdama. Izbojci su šiboliki, goli, sjajnozeleni i nahukani. Plod javora negundovca su svijetlosmeđe do sivkaste perutke, dužine $3-5 \mathrm{~cm}$, koje na ženskim stablima, u gustim grozdovima ostaju visjeti tijekom čitave zime (Idžojtić, 2005).

Robinia pseudoacacia L.

Obični bagrem je listopadno stablo visine 20 - 30 metara, s dobro razvijenim korijenovim sustavom, 


\section{Morfološki opis}

čije korijenje prodire u dubinu od oko 1,5 metra te u širinu više od 20 metara. Kora debla je sivosmeđe boje, uzdužno izbrazdana, dok je kod starijih stabala mrežasta s razgranjenim pukotinama (Hulina, 2011). Izbojci su tanki, uzdužno bridasti, koljeničasti i tanki tamno crvenkastosmeđe ili maslinastozelene boje, s trnjem u paru, lijevo i desno od pupa (Idžojtić, 2005). Plod je crnosmeđa mahuna promjera 1,5 do $2 \mathrm{~cm}$ i dužine oko $10 \mathrm{~cm}$, koja sadrži 6 do 8 sjemenki (Hulina, 2011).

Sljedeće fotografije (Slike 1. - 25.) prikazuju habitus, deblo i grane odabranih vrsta koje su ukrasne u zimskom razdoblju.

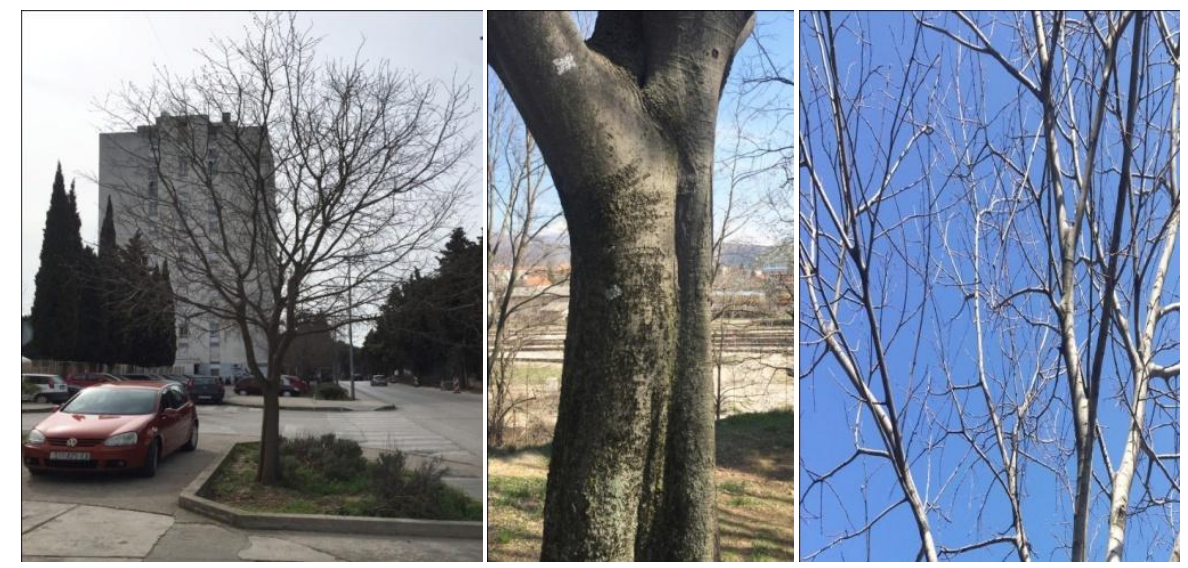

Slike 1. - 3. Fotografije habitusa, debla i grana - Celtis australis L. - koštela (Foto: Dorbić, 2017).

Figures 1. - 3. Photos of habitus, trunk and branches - Celtis australis L. - Mediterranean hackberry (Photo: Dorbić, 2017).

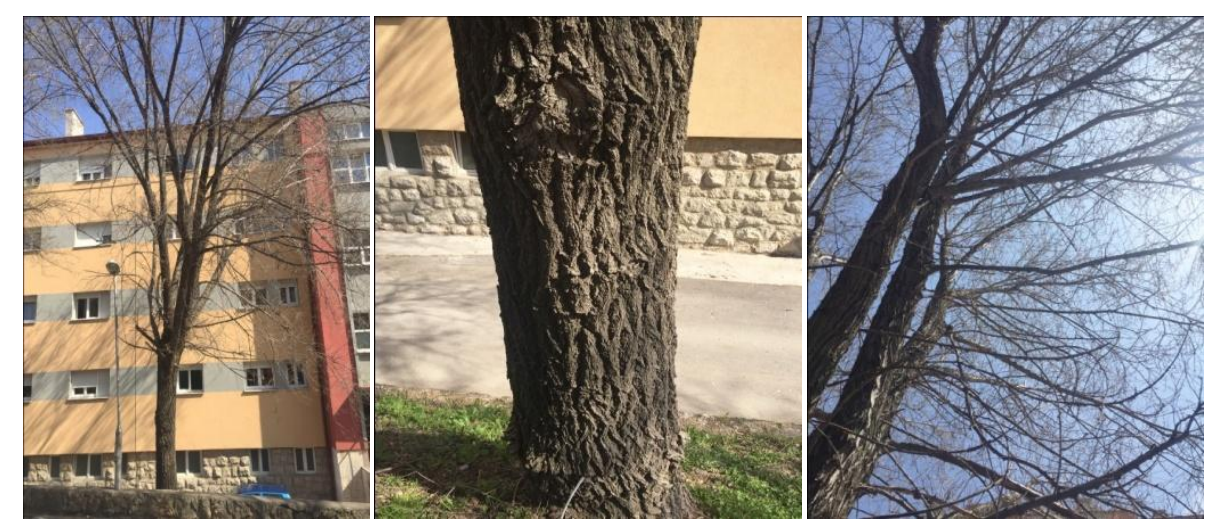

Slike 4. - 6. Fotografije habitusa, debla i grana - Ulmus pumila L. - sibirski brijest (Foto: Dorbić, 2017).

Figures 4. - 6. Photos of habitus, trunk and branches - Ulmus pumila L. - Siberian elm (Photo: Dorbić, 2017). 
B. Dorbić, Sandra Dukić, Emilija Friganović, Margarita Davitkovska, Zvezda Bogevska, Ana Vujošević, Sandra Popović / Percepcije i stavovi o ukrasn... / Glasilo Future (2018) 1 (4) 01-16

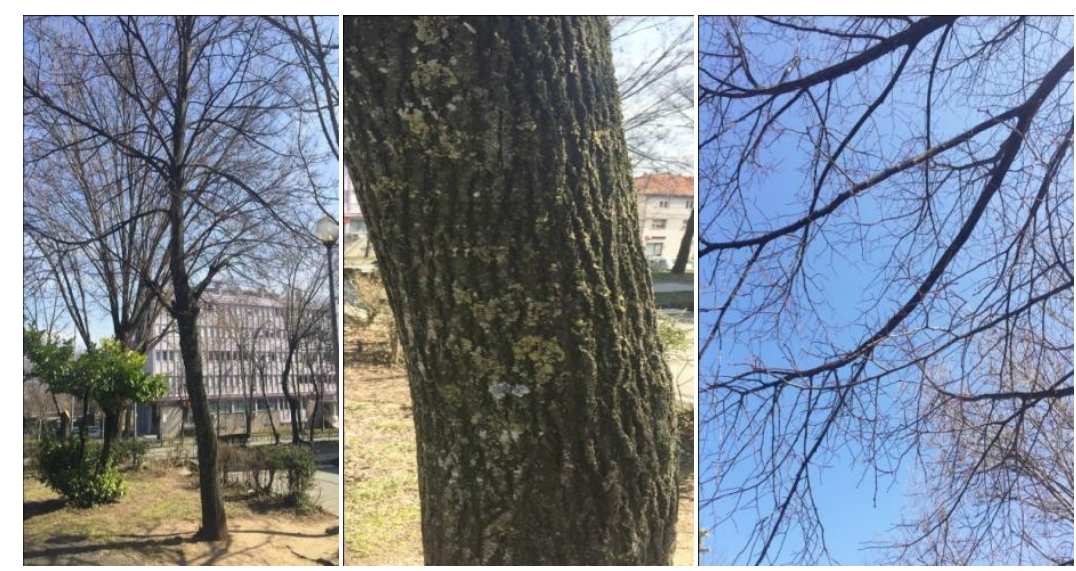

Slike 7. - 9. Fotografije habitusa, debla i grana - Tilia cordata Mill. - sitnolisna lipa (Foto: Dorbić, 2017).

Figures 7. - 9. Photos of habitus, trunk and branches - Tilia cordata Mill. - small-leaved lime (Photo: Dorbić, 2017).

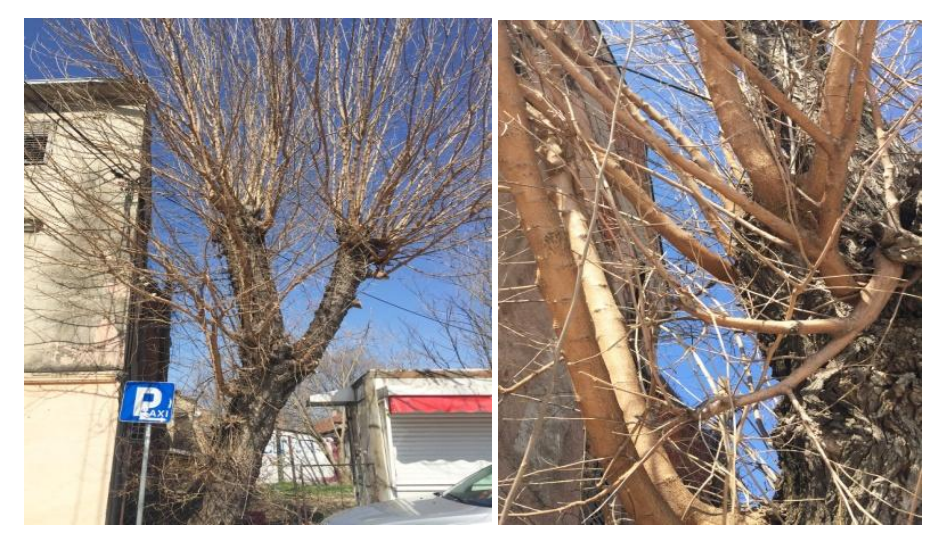

Slike 10. - 11. Fotografije habitusa i grana - Morus nigra L. - crni dud (Foto: Dorbić, 2017).

Figures 10. - 11. Photos of habitus and branches - Morus nigra L. - black mulberry (Photo: Dorbić, 2017).

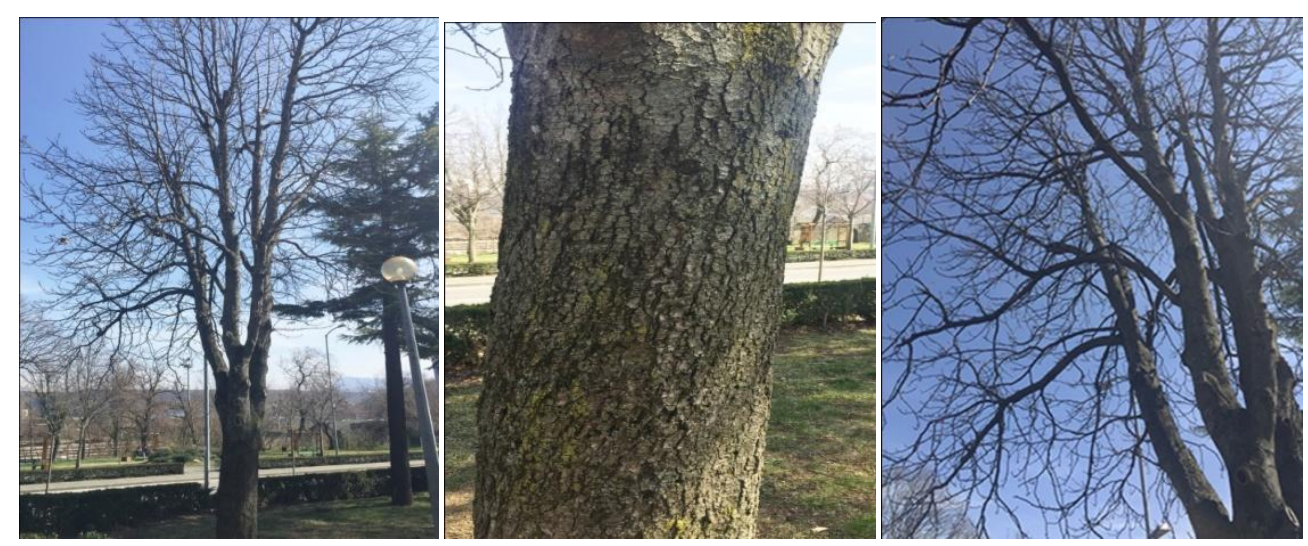

Slike 12. - 14. Fotografije habitusa, debla i grana - Aesculus hippocastanum L. - divlji kesten (Foto: Dorbić, 2017).

Figures 12. - 14. Photos of habitus, trunk and branches - Aesculus hippocastanum L. - horse chestnut trees (Photo: Dorbić, 2017). 
B. Dorbić, Sandra Dukić, Emilija Friganović, Margarita Davitkovska, Zvezda Bogevska, Ana Vujošević, Sandra Popović / Percepcije i stavovi o ukrasn... / Glasilo Future (2018) 1 (4) 01-16

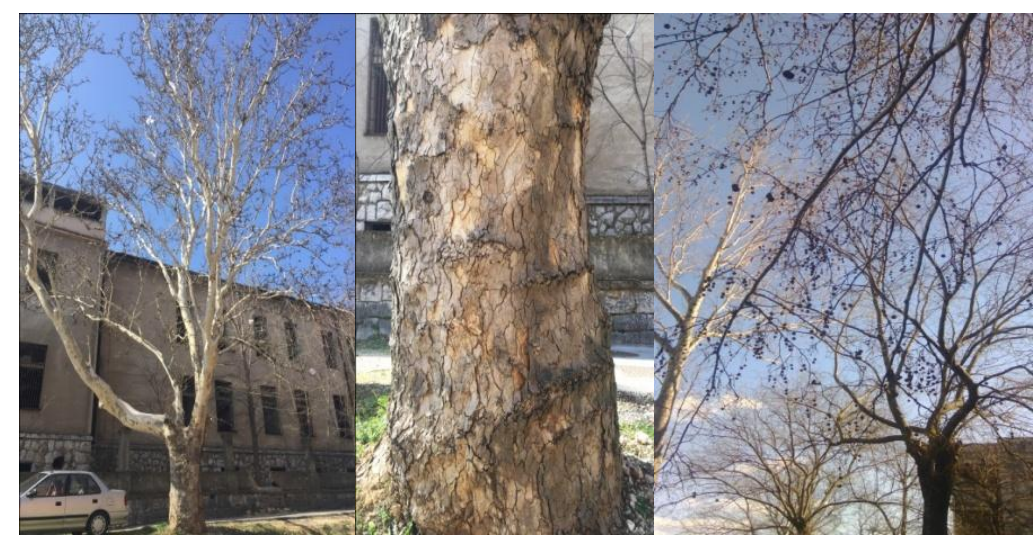

Slike 15. - 17. Fotografije habitusa, debla i grana - Platanus $x$ hispanica Münchh - hibridna platana (Foto: Dorbić, 2017).

Figures 15. - 17. Photos of habitus, trunk and branches - Platanus $x$ hispanica Münchh - hybrid plane (Photo: Dorbić, 2017).

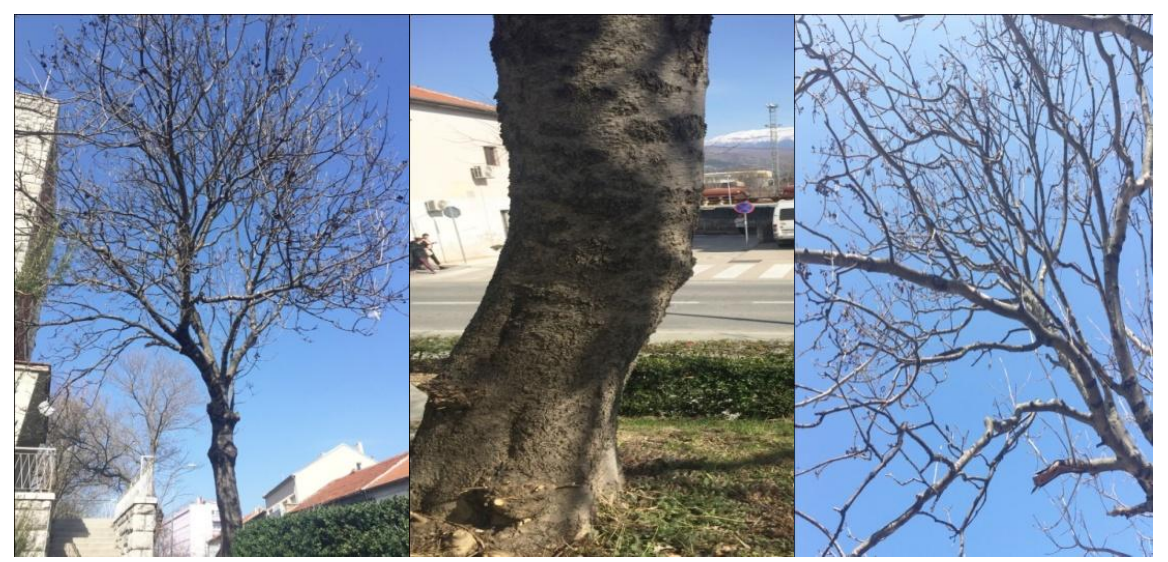

Slike 18. - 20. Fotografije habitusa, debla i grana - Fraxinus ornus L. - crni jasen (Foto: Dorbić, 2017).

Figures 18. - 20. Photos of habitus, trunk and branches - Fraxinus ornus L. - manna ash (Photo: Dorbić, 2017).
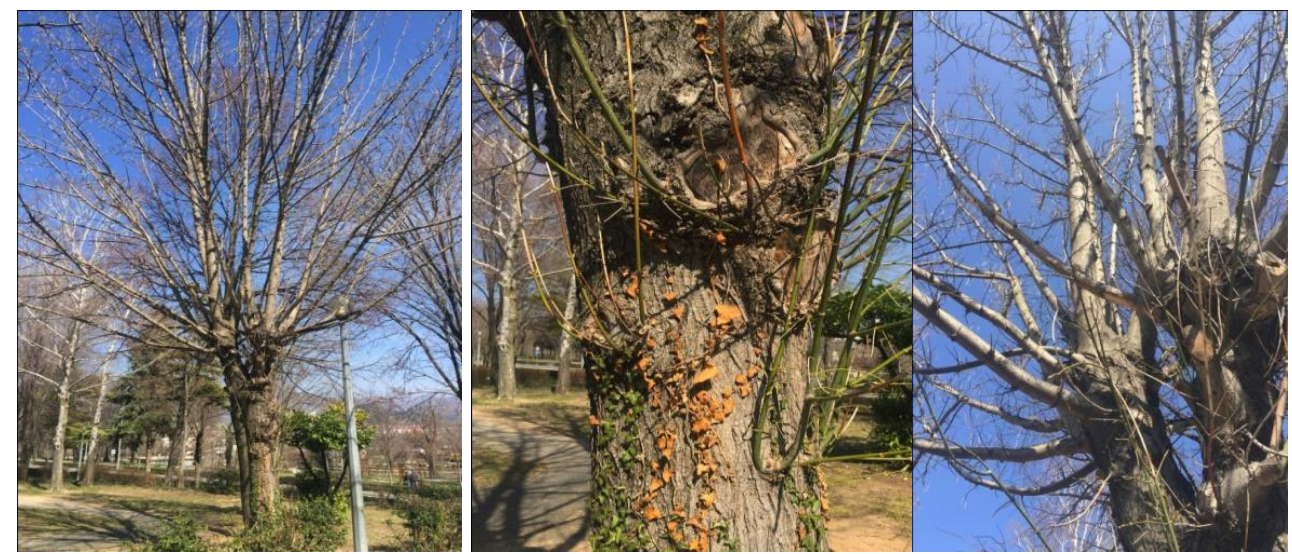

Slike 20. - 22. Fotografije habitusa, debla i grana - Acer negundo L. - javor negundovac (Foto: Dorbić, 2017).

Figures 20. - 22. Photos of habitus, trunk and branches - Acer negundo L. - ash-leaved maple (Photo: Dorbić, 2017). 

Ana Vujošević, Sandra Popović / Percepcije i stavovi o ukrasn... / Glasilo Future (2018) 1 (4) 01-16

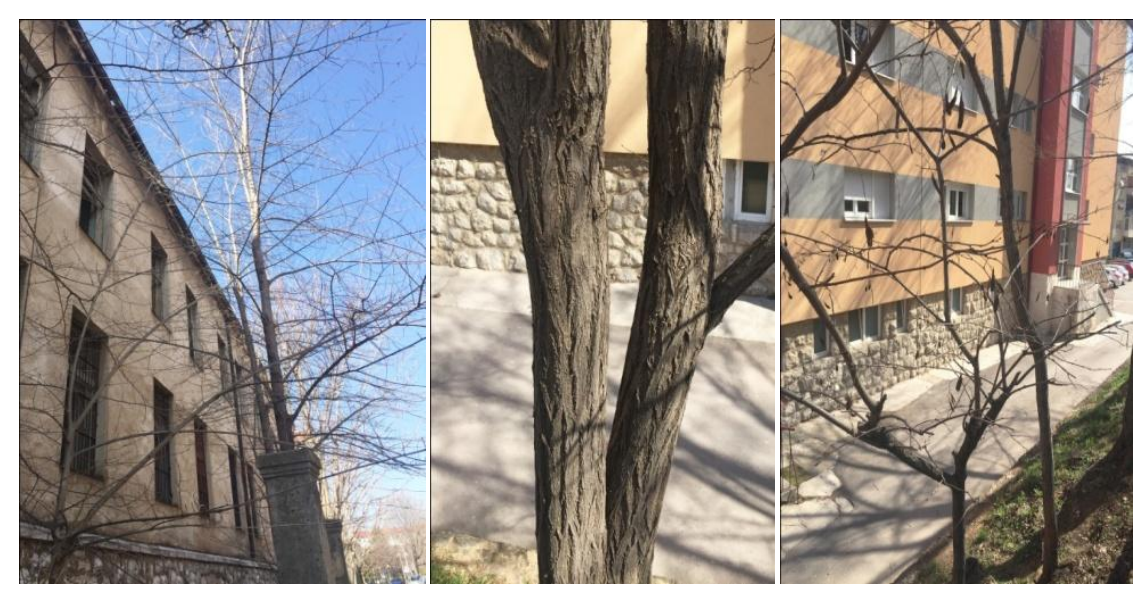

Slike 23. - 25. Fotografije habitusa, debla i grana - Robinia pseudacacia L. - obični bagrem (Foto: Dorbić, 2017).

Figures 23. - 25. Photos of habitus, trunk and branches - Robinia pseudacacia L. - black locust (Photo: Dorbić, 2017).

\section{Rezultati anketnog istraživanja}

$\mathrm{U}$ istraživačkom dijelu rada provedeno je anketno istraživanje s ciljem da se istraže stavovi i percepcije građana Knina i okolice o primjeni i ukrasnim karakteristikama submediteranskog drveća u zimskom razdoblju.

Tablica 2. Percepcije i stavovi o ukrasnim karakteristikama i primjeni koštele (Celtis australis L.) u zimskom razdoblju (Dukić, 2017).

Table 2. Perceptions and attitudes about ornamental characteristics and application of Mediterranean hackberry (Celtis australis L.) during the winter season (Dukić, 2017).

\begin{tabular}{|c|l|c|c|}
\hline \multicolumn{3}{|c|}{ 1. KOŠTELA } \\
\hline $\begin{array}{c}\text { Redni } \\
\text { br. }\end{array}$ & \multicolumn{1}{|c|}{$\begin{array}{c}\text { Pitanja } \\
\text { Ocjena 1 -5 }\end{array}$} & $\begin{array}{c}\text { Aritmetička } \\
\text { sredina }\end{array}$ & $\begin{array}{c}\text { Standardna } \\
\text { devijacija }\end{array}$ \\
\hline 1. & Ocijenite ukrasne karakteristike debla & 3,38 & 1,21 \\
\hline 2. & Ocijenite ukrasne karakteristike grana & 3,18 & 1,16 \\
\hline 3. & Ocijenite ukrasne karakteristike kore & 3,10 & 1,09 \\
\hline 4. & Ocijenite ukrasne karakteristike habitusa & 3,38 & 1,09 \\
\hline 5. & Ocijenite ukrasne karakteristike ploda & 3,52 & 1,05 \\
\hline 6. & $\begin{array}{l}\text { Ocijenite atraktivnost primjene vrste u vrtovima tijekom } \\
\text { zimskog razdoblja }\end{array}$ & 3,06 & 1,10 \\
\hline 7. & $\begin{array}{l}\text { Ocijenite atraktivnost primjene vrste na javnim } \\
\text { krajobraznim površinama i parkovima tijekom zimskog } \\
\text { razdoblja }\end{array}$ & 3,04 & 1,14 \\
\hline 8. & $\begin{array}{l}\text { Ocijenite utjecaj vrste u zimskom razdoblju na vašu psihu i } \\
\text { zdravlje. }\end{array}$ & 3,16 & 1,20 \\
\hline
\end{tabular}

Iz Tablice 2. je razvidno da ispitanici ocjenom dobar (iznad 3,0) vrednuju ukrasne karakteristike, primjenu te utjecaj koštele na ljudsku psihu i zdravlje u zimskom razdoblju. Ispitanici ocjenjuju ukrasne karakteristike ploda vrlo dobrom ocjenom $(3,52)$. 
B. Dorbić, Sandra Dukić, Emilija Friganović, Margarita Davitkovska, Zvezda Bogevska, Ana Vujošević, Sandra Popović / Percepcije i stavovi o ukrasn... / Glasilo Future (2018) 1 (4) 01-16

Tablica 3. Percepcije i stavovi o ukrasnim karakteristikama i primjeni sibirskoga brijesta (Ulmus pumila L.) u zimskom razdoblju (Dukić, 2017).

Table 3. Perceptions and attitudes about ornamental characteristics and application of Siberian elm (Ulmus pumila L.) during the winter season (Dukić, 2017).

\begin{tabular}{|c|l|c|c|}
\hline \multicolumn{3}{|c|}{ 2. SIBIRSKI BRIJEST } \\
\hline $\begin{array}{c}\text { Redni } \\
\text { br. }\end{array}$ & \multicolumn{1}{|c|}{$\begin{array}{c}\text { Pitanja } \\
\text { Ocjena 1 - 5 }\end{array}$} & $\begin{array}{c}\text { Aritmetička } \\
\text { sredina }\end{array}$ & $\begin{array}{c}\text { Standardna } \\
\text { devijacija }\end{array}$ \\
\hline 1. & Ocijenite ukrasne karakteristike debla & 3,02 & 1,24 \\
\hline 2. & Ocijenite ukrasne karakteristike grana & 2,88 &, 94 \\
\hline 3. & Ocijenite ukrasne karakteristike kore & 3,00 & 1,18 \\
\hline 4. & Ocijenite ukrasne karakteristike habitusa & 2,82 & 1,00 \\
\hline 5. & $\begin{array}{l}\text { Ocijenite atraktivnost primjene vrste u vrtovima } \\
\text { tijekom zimskog razdoblja }\end{array}$ & 2,80 &, 95 \\
\hline 6. & $\begin{array}{l}\text { Ocijenite atraktivnost primjene vrste na javnim } \\
\text { krajobraznim površinama i parkovima tijekom } \\
\text { zimskog razdoblja }\end{array}$ & 2,78 &, 97 \\
\hline 7. & $\begin{array}{l}\text { Ocijenite utjecaj vrste u zimskom razdoblju na vašu } \\
\text { psihu i zdravlje. }\end{array}$ & 2,92 & 1,14 \\
\hline
\end{tabular}

Iz Tablice 3. je razvidno da ispitanici ocjenom dobar $(2,78$ - 3,02) vrednuju ukrasne karakteristike, primjenu te utjecaj sibirskog brijesta na ljudsku psihu i zdravlje u zimskom razdoblju. Najveća ocjena $(3,02)$ je dodijeljena ukrasnim karakteristikama debla.

Tablica 4. Percepcije i stavovi o ukrasnim karakteristikama i primjeni sitnolisne lipe (Tilia cordata Mill.) u zimskom razdoblju (Dukić, 2017).

Table 4. Perceptions and attitudes about ornamental characteristics and application of small-leaved lime (Tilia cordata Mill.) during the winter season (Dukić, 2017).

\begin{tabular}{|c|l|c|c|}
\hline \multicolumn{3}{|c|}{ 3. SITNOLISNA LIPA } \\
\hline $\begin{array}{c}\text { Redni } \\
\text { br. }\end{array}$ & \multicolumn{1}{|c|}{$\begin{array}{c}\text { Pitanja } \\
\text { Ocjena 1 -5 }\end{array}$} & $\begin{array}{c}\text { Aritmetička } \\
\text { sredina }\end{array}$ & $\begin{array}{c}\text { Standardna } \\
\text { devijacija }\end{array}$ \\
\hline 1. & Ocijenite ukrasne karakteristike debla & 3,08 & 1,10 \\
\hline 2. & Ocijenite ukrasne karakteristike grana & 3,20 & 1,12 \\
\hline 3. & Ocijenite ukrasne karakteristike kore & 3,24 & 1,25 \\
\hline 4. & Ocijenite ukrasne karakteristike habitusa & 3,26 &, 96 \\
\hline 5. & $\begin{array}{l}\text { Ocijenite atraktivnost primjene vrste u vrtovima tijekom } \\
\text { zimskog razdoblja }\end{array}$ & 3,06 & 1,20 \\
\hline 6. & $\begin{array}{l}\text { Ocijenite atraktivnost primjene vrste na javnim krajobraznim } \\
\text { površinama i parkovima tijekom zimskog razdoblja }\end{array}$ & 3,14 & 1,18 \\
\hline 7. & $\begin{array}{l}\text { Ocijenite utjecaj vrste u zimskom razdoblju na vašu psihu i } \\
\text { zdravlje. }\end{array}$ & 3,28 & 1,14 \\
\hline
\end{tabular}

Iz Tablice 4. je razvidno da ispitanici ocjenom dobar (iznad 3,0) vrednuju ukrasne karakteristike, primjenu te utjecaj sitnolisne lipe na ljudsku psihu i zdravlje u zimskom razdoblju. Najveća ocjena dodijeljena je utjecaju vrste u zimskom razdoblju na ljudsku psihu i zdravlje $(3,28)$. 
B. Dorbić, Sandra Dukić, Emilija Friganović, Margarita Davitkovska, Zvezda Bogevska, Ana Vujošević, Sandra Popović / Percepcije i stavovi o ukrasn... / Glasilo Future (2018) 1 (4) 01-16

Tablica 5. Percepcije i stavovi o ukrasnim karakteristikama i primjeni crne murve (Morus nigra L.) u zimskom razdoblju (Dukić, 2018).

Table 5. Perceptions and attitudes about ornamental characteristics and application of black mulberry (Morus nigra L.) during the winter season (Dukić, 2018).

\begin{tabular}{|c|l|c|c|}
\hline \multicolumn{3}{|c|}{ 4. CRNA MURVA } \\
\hline $\begin{array}{c}\text { Redni } \\
\text { br. }\end{array}$ & \multicolumn{1}{|c|}{$\begin{array}{c}\text { Pitanja } \\
\text { Ocjena 1 - 5 }\end{array}$} & $\begin{array}{c}\text { Aritmetička } \\
\text { sredina }\end{array}$ & $\begin{array}{c}\text { Standardna } \\
\text { devijacija }\end{array}$ \\
\hline 1. & Ocijenite ukrasne karakteristike debla & 2,94 & 1,13 \\
\hline 2. & Ocijenite ukrasne karakteristike grana & 2,96 & 1,11 \\
\hline 3. & Ocijenite ukrasne karakteristike kore & 2,96 & 1,07 \\
\hline 4. & Ocijenite ukrasne karakteristike habitusa & 3,00 & 1,05 \\
\hline 5. & $\begin{array}{l}\text { Ocijenite atraktivnost primjene vrste u vrtovima tijekom } \\
\text { zimskog razdoblja }\end{array}$ & 2,88 &, 98 \\
\hline 6. & $\begin{array}{l}\text { Ocijenite atraktivnost primjene vrste na javnim krajobraznim } \\
\text { površinama i parkovima tijekom zimskog razdoblja }\end{array}$ & 2,92 &, 99 \\
\hline 7. & $\begin{array}{l}\text { Ocijenite utjecaj vrste u zimskom razdoblju na vašu psihu i } \\
\text { zdravlje. }\end{array}$ & 3,14 & 1,14 \\
\hline
\end{tabular}

Iz Tablice 5. je razvidno da ispitanici s područja grada Knina i okolice ocjenom dobar $(2,88-3,14)$ vrednuju ukrasne karakteristike, primjenu te utjecaj crne murve na ljudsku psihu i zdravlje u zimskom razdoblju. Ispitanici su najveću ocjenu dodijelili utjecaju vrste u zimskom razdoblju na ljudsku psihu i zdravlje (3,14).

Tablica 6. Percepcije i stavovi o ukrasnim karakteristikama i primjeni divljeg kestena (Aesculus hippocastanum L.) u zimskom razdoblju (Dukić, 2017).

Table 6. Perceptions and attitudes about ornamental characteristics and application of horse chestnut trees (Aesculus hippocastanum L.) during the winter season (Dukić, 2017).

\begin{tabular}{|c|l|c|c|}
\hline \multicolumn{3}{|c|}{ 5. DIVLJI KESTEN } \\
\hline $\begin{array}{c}\text { Redni } \\
\text { br. }\end{array}$ & \multicolumn{1}{|c|}{$\begin{array}{c}\text { Pitanja } \\
\text { Ocjena 1 - 5 }\end{array}$} & $\begin{array}{c}\text { Aritmetička } \\
\text { sredina }\end{array}$ & $\begin{array}{c}\text { Standardna } \\
\text { devijacija }\end{array}$ \\
\hline 1. & Ocijenite ukrasne karakteristike debla & 3,44 & 1,25 \\
\hline 2. & Ocijenite ukrasne karakteristike grana & 3,44 & 1,23 \\
\hline 3. & Ocijenite ukrasne karakteristike kore & 3,34 & 1,08 \\
\hline 4. & Ocijenite ukrasne karakteristike habitusa & 3,78 & 1,05 \\
\hline 5. & $\begin{array}{l}\text { Ocijenite atraktivnost primjene vrste u vrtovima tijekom } \\
\text { zimskog razdoblja }\end{array}$ & 3,42 & 1,07 \\
\hline 6. & $\begin{array}{l}\text { Ocijenite atraktivnost primjene vrste na javnim krajobraznim } \\
\text { površinama i parkovima tijekom zimskog razdoblja }\end{array}$ & 3,40 & 1,19 \\
\hline 7. & $\begin{array}{l}\text { Ocijenite utjecaj vrste u zimskom razdoblju na vašu psihu i } \\
\text { zdravlje. }\end{array}$ & 3,66 & 1,12 \\
\hline
\end{tabular}

Iz Tablice 6. je razvidno da ispitanici s područja grada Knina i okolice ocjenom dobar (iznad 3,0) vrednuju veći broj ukrasnih karakteristika i primjenu divljeg kestena u zimskom razdoblju. Ispitanici su dodijelili vrlo dobre ocjene ukrasnim karakteristikama habitusa $(3,78)$ i utjecaju vrste u zimskom 
B. Dorbić, Sandra Dukić, Emilija Friganović, Margarita Davitkovska, Zvezda Bogevska, Ana Vujošević, Sandra Popović / Percepcije i stavovi o ukrasn... / Glasilo Future (2018) 1 (4) 01-16

razdoblju na ljudsku psihu i zdravlje $(3,66)$.

Tablica 7. Percepcije i stavovi o ukrasnim karakteristikama i primjeni hibridne platane (Platanus $x$ hispanica Münchh) u zimskom razdoblju (Dukić, 2017).

Table 7. Perceptions and attitudes about ornamental characteristics and application of hybrid plane (Platanus $x$ hispanica Münchh) during the winter season (Dukić, 2017).

\begin{tabular}{|c|l|c|c|}
\hline \multicolumn{4}{|c|}{ 6. HIBRIDNA PLATANA } \\
\hline $\begin{array}{c}\text { Redni } \\
\text { br. }\end{array}$ & \multicolumn{1}{|c|}{$\begin{array}{c}\text { Pitanja } \\
\text { Ocjena 1 - 5 }\end{array}$} & $\begin{array}{c}\text { Aritmetička } \\
\text { sredina }\end{array}$ & $\begin{array}{c}\text { Standardna } \\
\text { devijacija }\end{array}$ \\
\hline 1. & Ocijenite ukrasne karakteristike debla & 3,58 & 1,18 \\
\hline 2. & Ocijenite ukrasne karakteristike grana & 3,42 & 1,13 \\
\hline 3. & Ocijenite ukrasne karakteristike kore & 3,48 & 1,07 \\
\hline 4. & Ocijenite ukrasne karakteristike habitusa & 3,70 & 1,07 \\
\hline 5 & Ocijenite ukrasne karakteristike ploda & 3,70 & 1,20 \\
\hline 6. & $\begin{array}{l}\text { Ocijenite atraktivnost primjene vrste u vrtovima tijekom } \\
\text { zimskog razdoblja }\end{array}$ & 3,62 &, 97 \\
\hline 7. & $\begin{array}{l}\text { Ocijenite atraktivnost primjene vrste na javnim krajobraznim } \\
\text { površinama i parkovima tijekom zimskog razdoblja }\end{array}$ & 3,44 &, 95 \\
\hline 8. & $\begin{array}{l}\text { Ocijenite utjecaj vrste u zimskom razdoblju na vašu psihu i } \\
\text { zdravlje. }\end{array}$ & 3,50 & 1,18 \\
\hline
\end{tabular}

Iz Tablice 7. je razvidno da ispitanici ocjenom vrlo dobar vrednuju veći broj ukrasnih karakteristika, primjenu te utjecaj hibridne platane na ljudsku psihu i zdravlje u listopadnom razdoblju u krajobrazu. Ispitanici su najveće ocjene dodijelili ukrasnim karakteristikama habitusa i ploda $(3,70)$.

Tablica 8. Percepcije i stavovi o ukrasnim karakteristikama i primjeni crnog jasena (Fraxinus ornus L.) u zimskom razdoblju (Dukić, 2017).

Table 8. Perceptions and attitudes about ornamental characteristics and application of manna ash (Fraxinus ornus L.) during the winter season (Dukić, 2017).

\begin{tabular}{|c|l|c|c|}
\hline \multicolumn{4}{|c|}{ 7. CRNI JASEN } \\
\hline $\begin{array}{c}\text { Redni } \\
\text { br. }\end{array}$ & \multicolumn{1}{|c|}{$\begin{array}{c}\text { Pitanja } \\
\text { Ocjena 1 -5 }\end{array}$} & $\begin{array}{c}\text { Aritmetička } \\
\text { sredina }\end{array}$ & $\begin{array}{c}\text { Standardna } \\
\text { devijacija }\end{array}$ \\
\hline 1. & Ocijenite ukrasne karakteristike debla & 3,12 & 1,10 \\
\hline 2. & Ocijenite ukrasne karakteristike grana & 3,28 & 1,23 \\
\hline 3. & Ocijenite ukrasne karakteristike kore & 3,20 & 1,03 \\
\hline 4. & Ocijenite ukrasne karakteristike habitusa & 3,48 & 1,18 \\
\hline 5. & $\begin{array}{l}\text { Ocijenite atraktivnost primjene vrste u vrtovima tijekom } \\
\text { zimskog razdoblja }\end{array}$ & 3,30 & 1,09 \\
\hline 6. & $\begin{array}{l}\text { Ocijenite atraktivnost primjene vrste na javnim krajobraznim } \\
\text { površinama i parkovima tijekom zimskog razdoblja }\end{array}$ & 3,22 & 1,11 \\
\hline 7. & $\begin{array}{l}\text { Ocijenite utjecaj vrste u zimskom razdoblju na vašu psihu i } \\
\text { zdravlje. }\end{array}$ & 3,40 & 1,21 \\
\hline
\end{tabular}

Iz Tablice 8. je razvidno da ispitanici ocjenom dobar (iznad 3,0) vrednuju ukrasne karakteristike primjenu te utjecaj crnog jasena na ljudsku psihu i zdravlje u zimskom razdoblju. Najbolje su 
B. Dorbić, Sandra Dukić, Emilija Friganović, Margarita Davitkovska, Zvezda Bogevska, Ana Vujošević, Sandra Popović / Percepcije i stavovi o ukrasn... / Glasilo Future (2018) 1 (4) 01-16

ocijenjene ukrasne karakteristike habitusa $(3,48)$.

Tablica 9. Percepcije i stavovi o ukrasnim karakteristikama i primjeni javora negundovca (Acer negundo L.) u zimskom razdoblju (Dukić, 2017).

Table 9. Perceptions and attitudes about ornamental characteristics and application of ash-leaved maple (Acer negundo L.) during the winter season (Dukić, 2017).

\begin{tabular}{|c|l|c|c|}
\hline \multicolumn{4}{|c|}{ 8. JAVOR NEGUNDOVAC } \\
\hline $\begin{array}{c}\text { Redni } \\
\text { br. }\end{array}$ & \multicolumn{1}{|c|}{$\begin{array}{c}\text { Pitanja } \\
\text { Ocjena 1 -5 }\end{array}$} & $\begin{array}{c}\text { Aritmetička } \\
\text { sredina }\end{array}$ & $\begin{array}{c}\text { Standardna } \\
\text { devijacija }\end{array}$ \\
\hline 1. & Ocijenite ukrasne karakteristike debla & 3,14 &, 97 \\
\hline 2. & Ocijenite ukrasne karakteristike grana & 3,16 &, 95 \\
\hline 3. & Ocijenite ukrasne karakteristike kore & 3,18 &, 90 \\
\hline 4. & Ocijenite ukrasne karakteristike habitusa & 3,28 &, 93 \\
\hline 5. & $\begin{array}{l}\text { Ocijenite atraktivnost primjene vrste u vrtovima tijekom } \\
\text { zimskog razdoblja }\end{array}$ & 2,92 & 1,01 \\
\hline 6. & $\begin{array}{l}\text { Ocijenite atraktivnost primjene vrste na javnim krajobraznim } \\
\text { površinama i parkovima tijekom zimskog razdoblja }\end{array}$ & 3,26 &, 96 \\
\hline 7. & $\begin{array}{l}\text { Ocijenite utjecaj vrste u zimskom razdoblju na vašu psihu i } \\
\text { zdravlje. }\end{array}$ & 3,20 & 1,01 \\
\hline
\end{tabular}

Iz Tablice 9. je razvidno da ispitanici ocjenom dobar (uglavnom iznad 3,0) vrednuju ukrasne karakteristike, primjenu te utjecaj javora negundovca na ljudsku psihu i zdravlje u zimskom razdoblju. Najveću ocjenu su dodijelili atraktivnost primjene vrste na javnim krajobraznim površinama i parkovima tijekom zimskog razdoblja $(3,26)$.

Tablica 10. Percepcije i stavovi o ukrasnim karakteristikama i primjeni bagrema (Robinia pseudacacia L.) u zimskom razdoblju (Dukić, 2017).

Table 10. Perceptions and attitudes about ornamental characteristics and application of black locust (Robinia pseudacacia L.) during the winter season (Dukić, 2017).

\begin{tabular}{|c|l|c|c|}
\hline \multicolumn{4}{|c|}{ 9. BAGREM } \\
\hline $\begin{array}{c}\text { Redni } \\
\text { br. }\end{array}$ & \multicolumn{1}{|c|}{$\begin{array}{c}\text { Pitanja } \\
\text { Ocjena 1 -5 }\end{array}$} & $\begin{array}{c}\text { Aritmetička } \\
\text { sredina }\end{array}$ & $\begin{array}{c}\text { Standardna } \\
\text { devijacija }\end{array}$ \\
\hline 1. & Ocijenite ukrasne karakteristike debla & 3,32 & 1,10 \\
\hline 2. & Ocijenite ukrasne karakteristike grana & 3,12 & 1,02 \\
\hline 3. & Ocijenite ukrasne karakteristike kore & 3,36 & 1,00 \\
\hline 4. & Ocijenite ukrasne karakteristike habitusa & 3,22 &, 86 \\
\hline 5. & Ocijenite ukrasne karakteristike ploda & 3,30 & 1,16 \\
\hline 6. & $\begin{array}{l}\text { Ocijenite atraktivnost primjene vrste u vrtovima tijekom } \\
\text { zimskog razdoblja }\end{array}$ & 3,10 & 1,13 \\
\hline 7. & $\begin{array}{l}\text { Ocijenite atraktivnost primjene vrste na javnim krajobraznim } \\
\text { površinama i parkovima tijekom zimskog razdoblja }\end{array}$ & 3,22 & 1,09 \\
\hline 8. & $\begin{array}{l}\text { Ocijenite utjecaj vrste u zimskom razdoblju na vašu psihu i } \\
\text { zdravlje. }\end{array}$ & 3,32 & 1,11 \\
\hline & \multicolumn{2}{|c|}{} \\
\hline
\end{tabular}

Iz Tablice 10. je razvidno da ispitanici ocjenom dobar (iznad 3,0) vrednuju ukrasne karakteristike, 
B. Dorbić, Sandra Dukić, Emilija Friganović, Margarita Davitkovska, Zvezda Bogevska, Ana Vujošević, Sandra Popović / Percepcije i stavovi o ukrasn... / Glasilo Future (2018) 1 (4) 01-16

primjenu te utjecaj bagrema na ljudsku psihu i zdravlje u zimskom razdoblju. Najveću ocjenu su dodijelili ukrasnim karakteristikama kore $(3,36)$.

Anketnim istraživanjem stavova i percepcije ispitanika s područja grada Knina i okolice, o primijeni i ukrasnim karakteristikama submediteranskog drveća u zimskom razdoblju, dobiveni su sumarni rezultati kako slijedi.

- Ispitanici prosječnom ocjenom dobar $(3,0)$ vrednuju ukrasne karakteristike, primjenu te utjecaj na ljudsku psihu i zdravlje za sljedeće vrste: koštela (Celtis australis L.), sibirski brijest (Ulmus pumila L.), sitnolisna lipa (Tilia cordata Mill.), crna murva (Morus nigra L.), divlji kesten (Aesculus hippocastanum L.), crni jasen (Fraxinus ornus L.), javor negundovac (Acer negundo L.) i obični bagrem (Robinia pseudacacia L.). Dobivene ocjene i ne iznenađuju jer su na našim prostorima početkom 20 stoljeća neke naše uobičajene vrste (npr. bijela murva) koje su bile lijepo uklopljene u mediteranski ambijent, nepravedno posječene i zamijenjene palmama (Grgurević, 2004).

- Mogu se izdvojiti i varijable koje su ocijenjene vrlo dobrim ocjenama: ukrasne karakteristike ploda koštele (C. australis) $(3,52)$ [koštela je našem puku osim za hladovinu bila i izvor "slatkih" jesenskih plodova te je oduvijek bila vezana za okućnicu (Dorbić et al., 2017)], ukrasne karakteristike habitusa divljeg kestena (A. hippocastanum) $(3,78)$ i njegov utjecaj na ljudsku psihu i zdravlje $(3,66)$.

- Ispitanici ocjenom vrlo dobar vrednuju veći broj ukrasnih karakteristika i primjenu hibridne platane (Platanus $x$ hispanica) u zimskom razdoblju. Vrsta im se najvjerojatnije više dopala zbog njenog neobičnog izgleda i manje primjene od gore navedenih vrsta. Premda su u prošlosti platane (Platanus sp.) bile zastupljenije u okviru kninskog gradskog zelenila (Dorbić i Temim, 2015) i danas u Kninu nalazimo markantne primjerke tih starih platana.

- Rezultati istraživanja mogu biti iskorišteni prilikom projektiranja različitih krajobraznih površina u smislu povećanja ugode i zadovoljstva korisnika.

\section{Zaključak}

Drveće dominira krajobrazom i daje karakter nekom prostoru, stvarajući ugodan krajobraz svojim oblikovnim karakteristikama, od kojih najveću važnost imaju njegove estetske, funkcionalne i strukturne osobine. Anketnim istraživanjem stavova i percepcije ispitanika s područja grada Knina i okolice o primijeni i ukrasnim karakteristikama submediteranskog drveća u zimskom razdoblju, dobiveni su rezultati gdje ispitanici prosječnom ocjenom dobar vrednuju ukrasne karakteristike, primjenu te utjecaj na ljudsku psihu i zdravlje kod većeg broja drvenastih vrsta. Dobivene ocjene (dobar) i ne iznenađuju jer su na našim prostorima početkom 20 stoljeća neke naše uobičajene, "obične" vrste koje su bile lijepo uklopljene u mediteranski ambijent, nepravedno posječene i 
B. Dorbić, Sandra Dukić, Emilija Friganović, Margarita Davitkovska, Zvezda Bogevska, Ana Vujošević, Sandra Popović / Percepcije i stavovi o ukrasn... / Glasilo Future (2018) 1 (4) 01-16 zamijenjene "egzotičnijim". Mogu se izdvojiti i varijable koje su ocijenjene vrlo dobrim ocjenama: ukrasne karakteristike ploda koštele (C. australis), ukrasne karakteristike habitusa divljeg kestena (A. hippocastanum) i njegov utjecaj na ljudsku psihu i zdravlje. Ispitanici ocjenom vrlo dobar vrednuju veći broj ukrasnih karakteristika i primjenu hibridne platane (Platanus x hispanica) u zimskom razdoblju. Rezultati istraživanja mogu biti iskorišteni u procesu krajobraznog planiranja.

\section{Zahvala}

Rad je izrađen u okviru izrade Završnog rada Sandre Dukić, BSc. polj: "Percepcije i stavovi o ukrasnim karakteristikama i primjeni submediteranskog listopadnog drveća u zimskom razdoblju" [Veleučilište "Marko Marulić" u Kninu (2017)].

\section{Literatura}

Dobrilovič, M. (2005). Odabir biljnog materijala u povijesti krajobraza. Agronomski glasnik, 67(2-4), 225-233.

Dorbić, B., Temim, E. (2014). Utjecaj zelenila i parkovnog modernizma na društveni život stanovnika šibensko-kninske županije. Agronomski glasnik, 76(6), 327-348.

Dorbić, B., Gverić, J. i Friganović, E. (2017). Inventarizacija voćnih vrsta i ukrasne dendroflore u vrtovima grada Skradina. Pomologia Croatica, 21(1-2), 91-100.

Dorbić, B., Temim, E. (2018). Valorizacija dendro-elemenata u parkovima i pejsažnim površinama na području Šibensko-kninske županije. Annales - Anali za Istrske in Mediteranske studije - Series Historia et Sociologia, 28(1), 167-192.

Dukić, S. (2007). Percepcije i stavovi o ukrasnim karakteristikama i primjeni submediteranskog listopadnog drveća u zimskom razdoblju. Završni rad. Veleučilište "Marko Marulić" u Kninu.

Grašo, K. (2005). Hortikulturno uređenje rive Lošinjskih Kapetana u Malom Lošinju. Agronomski glasnik, 67(2-4), 171-181.

Grgurević, D. (2004). Drvoredi u Splitu. Agronomski glasnik, 66(3-5), 197-206.

Hulina, N. (2011). Više biljke stablašice. Zagreb: Golden Marketing-Tehnička knjiga.

Idžojtić, M. (2005). Listopadno drveće i grmlje u zimskom razdoblju. Zagreb: Šumarski fakultet.

Kravanja, N. (2005). Odabir bilja prema ukusu korisnika gradskog prostora. Agronomski glasnik, $67(2-4), 88-96$.

Manojlović, R. (2005). Odabir bilja i prostor. Agronomski glasnik, 67(2-4), 107-114. 
B. Dorbić, Sandra Dukić, Emilija Friganović, Margarita Davitkovska, Zvezda Bogevska, Ana Vujošević, Sandra Popović / Percepcije i stavovi o ukrasn... / Glasilo Future (2018) 1 (4) 01-16

Rauš, Đ., Vukelić, J., Španjol, Ž. (1988). Bagremova šuma kao ispaša za pčele. Šumarski list, 7-8, 351-360.

Rosavec, R., Barčić, D., Španjol, Ž. (2005). Autohtone drvenaste vrste kao element naših mediteranskih urbanih zelenih prostora. Agronomski glasnik, 67(2-4), 121-151.

Šiftar, A. (2003). Suvremeno gradsko zelenilo između cvjetnjaka i spontane vegetacije. Zbornik sažetaka - Međunarodno interdisciplinarno savjetovanje "Njega gradskog prostora, boje u gradu vještina uređenja cvjetnjaka" Milas, Z. (ur.). Zagreb: Hrvatsko agronomsko društvo: 73-76.

Šilić, Ć. (1991). Atlas drveća i grmlja. Sarajevo: I.P. Svjetlost.

Šišić, B., Kapović, N. (2004). Drvoredi i obrubno zaštitno zelenilo uz gradske prometnice Dubrovnika. Agronomski glasnik, 66(3-5), 227-248.

Vukičević, E. (1987). Dekorativna dendrologija. Beograd: Naučna knjiga.

Židovec, V., Karlović, K. (2005). Primjena autohtonog bilja u uređenju gradskih prostora. Agronomski glasnik, 67(2-4), 151-158.

Primljeno: 15. prosinca 2018. godine

Received: December 15, 2018

Prihvaćeno: 31. prosinca 2018. godine

Accepted: December 31, 2018 